Sains Malaysiana 50(6)(2021): 1651-1662

http://doi.org/10.17576/jsm-2021-5006-12

\title{
Toxins of Foodborne Pathogen Bacillus cereus and the Regulatory Factors Controlling the Biosynthesis of Its Toxins
}

(Toksin daripada Patogen Bawaan Makanan Bacillus cereus dan Faktor Kepengawalaturan yang Mengawal

Biosintesis Toksinnya)

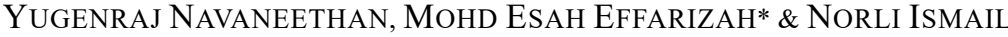

\begin{abstract}
Bacillus cereus is a versatile organism which causes two distinct types of food poisoning by producing toxins. Toxin formation in $\mathrm{B}$. cereus is very much a complex process involving co-regulation of multiple genes exerting control at transcriptional, translational and post-translational level and such regulations too are often influenced by extrinsic factors. A comprehensive understanding of such factors is very crucial for holistic approaches and strategies in order to minimise food poisoning risk. Hence, this review will focus on the intrinsic and extrinsic factors controlling toxin biosynthesis in $\mathrm{B}$. cereus.
\end{abstract}

Keywords: Bacillus cereus; emetic toxin; enterotoxins; gastroenteritis; virulence genes

\section{ABSTRAK}

Bacillus cereus adalah organisma serba boleh yang menyebabkan dua jenis keracunan makanan yang berbeza dengan menghasilkan toksin. Pembentukan toksin dalam B. cereus merupakan satu proses yang sangat kompleks melibatkan pengawalaturan pelbagai gen yang menjalankan kawalan pada tahap transkripsi, translasi and pascatranslasi manakala pengawalaturan tersebut sering dipengaruhi oleh faktor ekstrinsik. Pemahaman yang komprehensif mengenai faktor tersebut adalah sangat penting untuk pendekatan dan strategi yang holistik bagi mengurangkan risiko keracunan makanan. Oleh itu, tinjauan ini akan memberi tumpuan pada faktor intrinsik dan ekstrinsik yang mengawal biosintesis toksin dalam $\mathrm{B}$. cereus.

Kata kunci: Bacillus cereus; enterotoksin; gastroenteritis; gen kevirulenan; toksin emetik

\section{INTRODUCTION}

Formation of endospores and biofilm in several Bacillus species (Majed et al. 2016; Oh \& Cox 2010) serves as a survival strategy to adapt to the changes in environment and in turn, has paved the way for the evolution of these organisms (Guinebretière et al. 2013; Majed et al. 2016). This is clearly reflected in terms of diversity of DNA sequences and gene expression of genus Bacillus as well as their wide spectrum of phenotypic characteristics which enable them to inhabit various ecological niches (Ehling-Schulz et al. 2015).

Although most of the Bacillus species are regarded as harmless contaminants, the subsequent outgrowth of thermoduric spores of pathogenic Bacillus and hydrophobicity of spores have always remained a big challenge to the food and dairy industries (Oh \& Cox 2010; Soni et al. 2016). B. cereus is the most predominant species of genus Bacillus and is found ubiquitously in various environments such as soil, plant roots, sediments, dust, and water (Oh \& Cox 2010; Rouzeau-Szynalski et al. 2020; Tewari et al. 2015). As a result of its ubiquitous distribution, $B$ cereus easily enters food processing and production chains, and contaminate several food products (Tewari et al. 2015) such as cooked rice, vegetables, meats, spices and dairy products (Carter et al. 2018; Svensson et al. 2007; Yu et al. 2020). 
The pathogenic strains of $B$. cereus are responsible for several non-gastrointestinal (Bottone et al. 2010) and gastrointestinal illnesses (Carroll et al. 2019). Pertaining to the gastrointestinal illnesses, $B$. cereus acts as a causative agent of food poisoning which can be categorised into emetic or diarrheal depending on the illnesses caused upon ingestion of contaminated foods (Carroll et al. 2019). The emetic syndrome which is caused by heat-stable emetic (cereulide) toxin, usually exhibits symptoms such as vomiting and nausea (Yu et al. 2020), occurring after 0.5 to $6 \mathrm{~h}$ of ingestion of contaminated foods (Lücking et al. 2015).

Diarrheal syndrome is characterised by abdominal pain, cramps and diarrhea after 8 to $16 \mathrm{~h}$ of ingestion (Svensson et al. 2007). This form of food poisoning is caused by a group of heat-labile enterotoxins such as haemolysin BL (Hbl), nonhaemolytic enterotoxin (Nhe) cytotoxin $\mathrm{K}$ (CytK), and enterotoxin FM (EntFM) (Carter et al. 2018). The B. cereus toxins (emetic or diarrheal) usually cause less severe symptoms though certain highly severe cases involving hospitalisations and deaths were reported (Ehling-Schulz et al. 2015). The variations in severity of $B$. cereus illnesses from one outbreak to another, certainly indicate that toxin formation in B. cereus is highly complex and factors involved in such highly complex regulations of toxin synthesis are discussed herewith.

\section{EMETIC TOXIN OF B. cereus AND ITS REGULATORY FACTORS EMETIC TOXIN}

Emetic toxin is also known as cereulide, which is a small, hydrophobic and cyclic dodecadepsipeptide (D-O-Leu-
D-Ala-L-O-Val-L-Val) ${ }_{3}$ (Ehling-Schulz et al. 2005; Phat et al. 2016) with a molecular weight of approximately 1.2 $\mathrm{kDa}$ (Kranzler et al. 2016). Emetic toxin and its chemical structure (Figure 1) were first described by Agata et al. (1994). This toxin is a very stable molecule as it is resistant towards heat, $\mathrm{pH}$ and proteases (Lücking et al. 2015; Phat et al. 2016). The chemical structure of cereulide which is homologous to potassium ionophore valinomycin, indicates that it is synthesised nonribosomally by peptide synthetases, specifically by cereulide synthetase (ces) gene (Kranzler et al. 2016).

This emesis causing toxin is usually pre-synthesised in the contaminated foods which are mostly farinaceous food matrices such as rice (Toh et al. 2004). The toxin produced, cereulide, causes emesis by binding to serotonin 5 -HT $_{3}$ (5-hydroxytryptamine) receptor and stimulates vagus afferent following release from stomach (Arnesen et al. 2008). The cytotoxicity of cereulide damages several cells such as liver cells (Saleh et al. 2012), natural killer cells (Paananen et al. 2002) and beta cells (Vangoitsenhoven et al. 2014).

In terms of cytotoxicity towards natural killer cells, the threshold concentration for cereulide is much lower than that of valinomycin due to its highly lipophilic nature of cereulide which confer better penetrative abilities than valinomycin (Paananen et al. 2002). Similarly, the findings of Vangoitsenhoven et al. (2014) also indicated low doses of cereulide affects beta cells. The deleterious effect of cereulide observed on insulin-secreting beta cells raises suspicion as to whether cereulide contamination has a role in the development of Type 2 diabetes. Cereulide intoxications have occasionally resulted in severe outcomes, as described in Table 1.

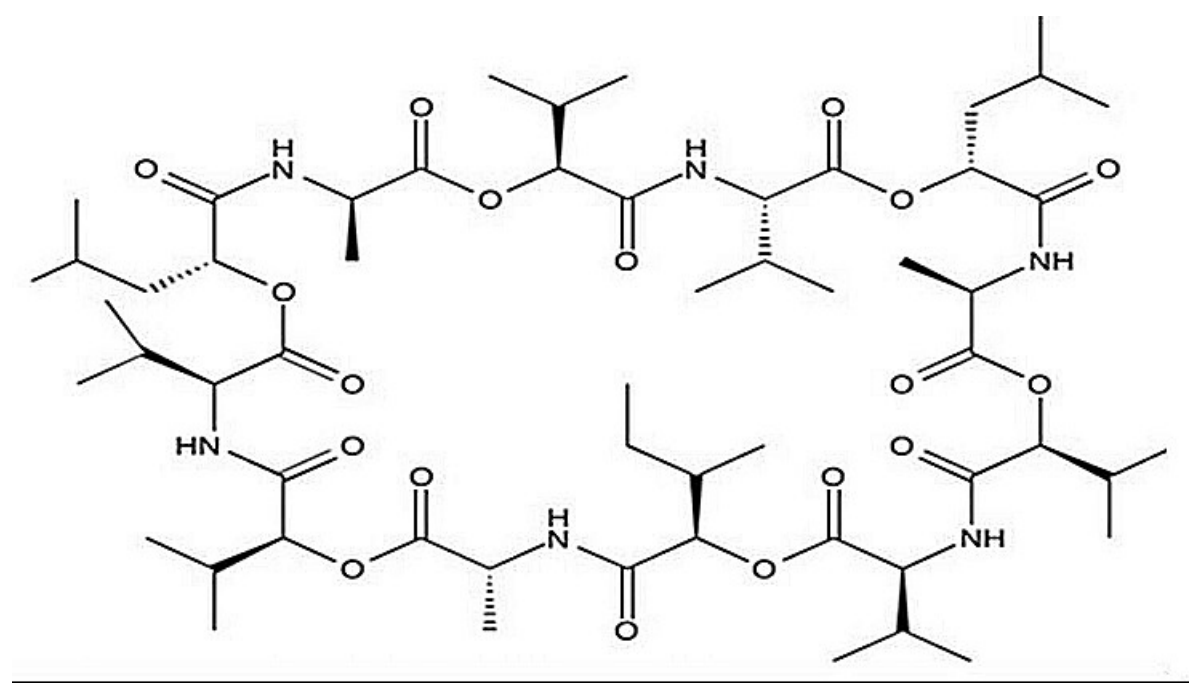

FIGURE 1. Chemical structure of cereulide (Agata et al. 1994; Ehling-Schulz et al. 2006) 
TABLE 1. Examples of severe $B$. cereus cereulide intoxication cases

\begin{tabular}{|c|c|c|}
\hline Country & Details & References \\
\hline Belgium & $\begin{array}{l}\text { Fulminant liver failure and rhabdomyolysis following ingestion of cereulide- } \\
\text { containing foods which have caused death of a } 17 \text {-year old boy }\end{array}$ & Mahler et al. (1997) \\
\hline Belgium & $\begin{array}{l}\text { Consumption of cereulide-contaminated foods resulted in fatal liver failure } \\
\text { involving } 5 \text { individuals of a family }\end{array}$ & Dierick et al. (2005) \\
\hline Japan & $\begin{array}{l}\text { Development of acute encephalopathy and liver failure in an 11- year old } \\
\text { patient whose gastric fluid and stool specimens were positive for emetic toxin. }\end{array}$ & Ichikawa et al. (2010) \\
\hline & No casualty & \\
\hline Belgium & $\begin{array}{l}\text { Sudden death of a } 20 \text {-year old man after consumption of left-over spaghetti } \\
\text { meal which was positive for B. cereus and high content of cereulide }\end{array}$ & Naranjo et al. (2011) \\
\hline France & $\begin{array}{l}\text { Reversible fulminant liver failure in } 15 \text {-year old patient whose stool specimen } \\
\text { was positive for ces-bearing B. cereus }\end{array}$ & Saleh et al. (2012) \\
\hline
\end{tabular}

\section{INTRINSIC FACTORS CONTROLLING EMETIC TOXIN PRODUCTION}

The molecular organisation (Figure 2) of $24 \mathrm{kbp}$ ces gene cluster was first described by Ehling-Schulz et al. (2006). Cereulide-synthesising gene cluster comprises cesPTABCD in an operon which is polycistronically transcribed and ces $H$ which is transcribed independent from the other ces genes (Tian et al. 2019). Unlike the former genetic elements, ces $H$ acts as cereulide repressor (Lücking et al. 2015; Tian et al. 2019). The inhibitory effect of $c e s H$ on emetic toxin is crucial to ensure nutrients are sufficient for other physiological processes and not fully utilised for toxin production (Tian et al. 2019). Interestingly, the expression of ces genes does not always follow the principle of collinearity as 18 other cereulide variants (isocereulides) with differing toxicities have been identified (Marxen et al. 2015). The variation in ces gene products certainly does not arise from genetic variation as Kranzler et al. (2016) and Marxen et al. (2015) reported production of isocereulides from a single strain.

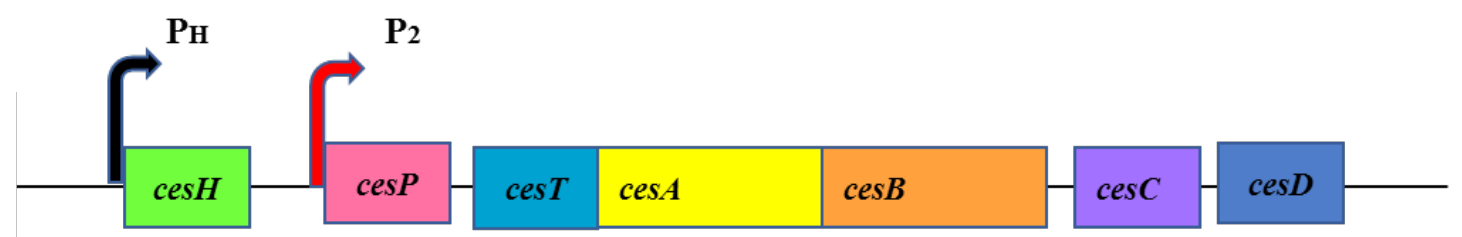

FIGURE 2. Genetic arrangement of cereulide synthethase gene cluster in emetic $B$. cereus strain F4810/72. The ces locus consists of seven open reading frames (ORF) which are cesH (encodes hydrolase/acetyltransferase), ces $P$ (phosphopantetheinyl transferase for activation of Nonribosomal peptide synthethase enzymes), $\operatorname{ces} T$ (a Type II thioesterase for removal of misprimed monomers), ces $A B$ (incorporation of monomers in peptide chain) and $c e s C D$ (putative ATP-binding cassette transporter involved in cereulide transport). Bent arrows indicate identified promoters. Polycistronic transcription of genes in ces operon (except ces $H$ ) is driven by promoter highlighted in red (Ehling-Schulz et al. 2006; Lücking et al. 2015) 
The genetic determinants of cereulide biosynthesis are located on a mega virulence plasmid, showing high similarity (about 85 to $99 \%$ ) to pXO1 plasmid of $B$. anthracis (Ehling-Schulz et al. 2006), indicating that both plasmids may share common ancestry. Despite the homology, Rasko et al. (2007) showed that pXO1-like plasmid of emetic B. cereus F4810/72 (pCER270 or pBCE4810) was devoid of pXO1 borne- pathogenicity island (PI) which had been substituted with plasmidspecific DNA containing emetic toxin biosynthetic gene cluster. In addition to ces gene, a region on emetic $B$. cereus plasmid harbor chromosomally encoded gene homologs which play roles in sporulation, germination and formaldehyde detoxification (Rasko et al. 2007).

The presence of these homologs on plasmid in combination with corresponding chromosomal genes, will probably confer advantages in terms of resistance, virulence and metabolic regulations particularly in the event of mutations to chromosomal genes. For instance, an $18 \mathrm{~kb}$ region characteristic of pCER 270 plasmid was found to encode several proteins including small acidsoluble proteins (Rasko et al. 2007) which stabilise spore DNA and confer resistance to bacterial spores against desiccation, toxic chemicals, dry and wet heat (Setlow 2014). This perhaps explains the higher resistance of emetic $B$. cereus strains than their diarrheal counterparts, as reported by Carlin et al. (2006).

There is no correlation between cereulide synthesis and sporulation although both aspects were initially thought to be linked (Häggblom et al. 2002). Finlay et al. (2000) reported that production of large number of spores can occur without any detectable cereulide toxin, indicating that the toxin is not a component of spore cells. This finding is further reinforced through the results reported by Häggblom et al. (2002) in which spore production was noted much later after the synthesis of cereulide, indicating both processes occur independently. Although emetic toxin synthesis occurs irrespective of sporulation, the master sporulation regulator of Spo0A plays a role in cereulide synthesis.

The Spo0A regulator consists of sigma factor A $\left(\sigma^{\mathrm{A}}\right)$ and sigma factor $\mathrm{H}\left(\sigma^{\mathrm{H}}\right)$ (Ehling-Schulz et al. 2015). Lücking et al. (2009) demonstrated that recombinant strain F48Dspo0AcomAH (bearing both $\sigma^{\mathrm{A}}$ and $\sigma^{\mathrm{H}}$ ) showed cytotoxicity towards HEp-2 cells whereas recombinant strain F48Dspo0AcomH (bearing $\sigma^{\mathrm{H}}$ but no $\sigma^{\mathrm{A}}$ ) exhibited low level of cytotoxicity. In the same study, plcR null mutant strain exhibited same level of cytotoxicity as the wild-type. This clearly indicates that $\mathrm{PlcR}$ regulator is not involved in the regulation of ces gene although it regulates several other virulence factors (enterotoxins) in B. cereus and B. thuringiensis (Lücking et al. 2009).

Instead, it is the $\operatorname{Spo} 0 \mathrm{~A}$, particularly $\sigma^{\mathrm{A}}$ that regulates and controls the cereulide biosynthesis in emetic B. cereus (Ehling-Schulz et al. 2015; Lücking et al. 2009). Spo0A does not directly control the expression of ces gene as the gene cluster is typically devoid of ' $0 \mathrm{~A}$ box'. Hence, Spo0A acts by repressing transcription factor, AbrB which acts as negative regulator of emetic toxin (Lücking et al. 2009). In the study conducted by Lücking et al. (2009), double mutant strain F48DabrBDspo0A (lacking both $a b r$ and $\operatorname{spo} 0 A$ ) had higher toxin production than that of wild-type strain.

These results highlight the involvement of other regulatory mechanisms in modulating cereulide synthesis apart from Spo0A-AbrB dependent regulation. For instance, Frenzel et al. (2012) have showed that ces genes are repressed in the presence of CodY. Repression of cereulide synthesis occurs by binding of CodY to the promoter of ces operon which is enhanced by the presence of branched-chain amino acids (BCAA) such as leucine and valine. This finding is, however rather peculiar since from the chemical structure of cereulide (D-O-Leu-D-AlaL-O-Val-L-Val), BCAAs are apparently used as building block in the toxin synthesis and therefore is expected to enhance toxin production.

In accordance to the expectation, Agata et al. (1999) demonstrated that group A amino acids consisting of valine, leucine, and threonine are essential for bacterial growth. Jääskeläinen et al. (2004) too reported similar findings, in which inoculated rice spiked with L-leucine and L-valine which resulted in higher toxin titre. The contradicting results of all these studies highlight how these amino acids can concomitantly act as cereulide precursor and CodY activator depending on bacterial growth stage (EhlingSchulz et al. 2015; Frenzel et al. 2012).

For instance, transcriptional analysis by Frenzel et al. (2012) showed that plcR expression (upregulated by $\mathrm{CodY}$ ) were high in early growth phases in emetic $B$. cereus and ceased in later growth phases. Similarly, CodY-mediated repression of $i l v E$ (codes for BCAA aminotransferase) and inhAl (codes for immune-inhibitor metalloprotease) genes were reported to decline in the late logarithmic and subsequent growth phases (Frenzel et al. 2012), indicating the decrease in CodY protein amount in later bacterial growth stages, in which cereulide synthesis is reported to commence (Häggblom et al. 2002). These findings clearly indicate growth phase-dependent 
regulation of emetic toxin production by CodY and such a strict temporal regulation explains the possibility of how amino acids can act as both cereulide precursor and repressor.

\section{EXTRINSIC FACTORS CONTROLLING EMETIC TOXIN PRODUCTION}

Extrinsic factors also affect emetic toxin production and the effects of such factors like temperature, $\mathrm{pH}$, types of foods, oxygen, and type of incubation on cereulide production had been investigated by a number of studies. Finlay et al. (2000) reported that at the lower temperature limit $\left(12{ }^{\circ} \mathrm{C}\right)$, the quantity of toxin produced was significantly higher than at any higher incubation temperatures. In a more recent study, Kranzler et al. (2016) found higher toxin titre at $37^{\circ} \mathrm{C}$. The discrepancies between the two findings occur possibly due to differences in the strain and inoculation media used.

However, both studies presented similar findings in which no cereulide was detected at temperatures of $46^{\circ} \mathrm{C}$ and above, although certain emetic strains were able to grow (Apetroaire-Constantin et al. 2008; Carlin et al. 2006; Finlay et al. 2000; Kranzler et al. 2016). These findings clearly highlight that foods stored at or above-mentioned temperature before toxin formation are unlikely to be vehicle for emetic foodborne illnesses. This demonstrates the importance of temperatures in Hazard Analysis and Critical Control Point (HACCP) to ensure food safety. The effect of temperatures on cereulide synthesis however can be influenced by culture media.

The study by Apetroaie-Constantin et al. (2008) had shown that higher cereulide amount (310 to $920 \mathrm{ng} / \mathrm{mg}$ ) was produced by F4810/72 strain upon growth on tryptic soy agar at 20 to $23{ }^{\circ} \mathrm{C}$, contrary to only 70 to $77 \mathrm{ng} / \mathrm{mg}$ cereulide at $37^{\circ} \mathrm{C}$ on similar agar. However, on Oatmeal agar, the same strain exhibited about two-fold increase in cereulide content at $37{ }^{\circ} \mathrm{C}$. Moreover, no growth and cereulide production was observed following inoculation of F4810/72 strain onto Oatmeal agar beyond $39{ }^{\circ} \mathrm{C}$ (Apetroaie-Constantin et al. 2008) though the same strain had viable count at up to $48{ }^{\circ} \mathrm{C}$ on Plate Count (PC) broth (Carlin et al. 2006) and minimal cereulide content at up to $42{ }^{\circ} \mathrm{C}$ on tryptic soy agar (Häggblom et al. 2002). These findings reinforce that regulatory effects of temperature on emetic $B$. cereus growth and subsequent emetic toxin production are also dependent on composition of culture media (nutrients).

As nutrients play crucial role in the regulation of cereulide formation, it is also common for production of cereulide to vary according to the food matrices (Rouzeau-
Szynalski et al. 2020). Farinaceous foods such as rice enable cereulide to be produced in higher quantities as compared to proteinaceous foods such as milk and eggs (Agata et al. 2002). The stimulating effect of glucose on cereulide synthesis as reported by Agata et al. (1999) and Tian et al. (2019) explains why such a food matrix is often implicated with emetic $B$. cereus and cereulide production. In spite of that, Shaheen et al. (2006) reported that some infant formulas are very good substrates for cereulide production and similar findings stating milk powder as a high-risk product for cereulide synthesis had been reported by Messelhäusser et al. (2014). Despite high frequency of $B$. cereus isolation from milk and dairy products, only a few food poisoning outbreaks implicating dairy products have been reported possibly due to visible symptoms of product spoilage which hinder consumption and poorer ability of psychrotropic strains to germinate in intestinal tract (Burgess \& Horwood 2006; Svensson et al. 2007).

Apart from nutrient composition of foods, the $\mathrm{pH}$ and water activity $\left(\mathrm{a}_{\mathrm{w}}\right)$ of foods also determine its ability to support bacterial growth and toxin production. Carlin et al. (2006) reported that cereulide formation took place in the $\mathrm{pH}$ range of 4.6 to 7.5 and $\mathrm{a}_{\mathrm{w}}$ of 0.929 to 0.996 . This finding was in agreement with that of Jääskeläinen et al. (2003) who found bakery products with high cereulide content had nearly neutral $\mathrm{pH}$ of about 6.2 and $\mathrm{a}_{\mathrm{w}}$ of 0.98 . It is likely that $\mathrm{pH}$ and water activity of foods do not directly affect toxin synthesis, but rather regulate bacterial growth and other metabolic processes which then either enhance or suppress toxin production.

The presence of oxygen is necessary for emetic toxin synthesis as the toxin was produced only under aerobic and microaerobic conditions (Finlay et al. 2002). Similar finding was reported by Jääskeläinen et al. (2004) in which suppression of cereulide synthesis occurred in the absence of oxygen. The fact that cereulide is pre-synthesised in foods rather than in gastrointestinal tract, corroborates the findings of those studies and emphasises the importance of oxygen presence for the production of emesis-causing toxin unlike for bacterial growth, and synthesis of enterotoxins which may occur independent of oxygen availability (Finlay et al. 2002; Jääskeläinen et al. 2004).

Studies have reported that incubation of cultures with shaking yields higher titre of toxin than in static incubation (Agata et al. 2002; Finlay et al. 2002; Häggblom et al. 2002). On the contrary, the results presented by Rajkovic et al. (2006) and Shaheen et al. (2006) found higher cereulide accumulations in statically incubated samples than in samples under shaking. Since the role of oxygen in cereulide production is proven, it is likely that shaking 
cultures might yield higher cereulide titre. However, it must also be noted that there were differences in terms of culture media composition and bacterial strains used in these studies which might have been responsible for the contradicting results observed.

\section{ENTEROTOXINS OF B. cereus AND ITS REGULATORY FACTORS ENTEROTOXINS}

$B$. cereus enterotoxins are a group of heat-labile proteins which cause diarrheal syndromes or toxico-infections (Carroll et al. 2019; Yu et al. 2020). B. cereus enterotoxins are only formed in the host's intestine during its vegetative growth (Carter et al. 2018). These enterotoxins comprise haemolysin BL ( $\mathrm{Hbl}$ ), nonhaemolytic enterotoxin (Nhe), cytotoxin K (CytK), and enterotoxin FM (EntFM) (Yu et al. 2020). Table 2 shows the description of B. cereus enterotoxin genes and proteins. Although enterotoxin $\mathrm{T}$ (BceT) was initially reported to be a part of $B$. cereus enterotoxins (Agata et al. 1995), it was later found that this protein was devoid of biological activity required to cause food poisoning (Choma \& Granum 2002). Moreover, Hansen et al. (2003) confirmed that BceT enterotoxin does not exist as initially reported because it is just a chimeric protein formed during cloning.

TABLE 2. Description of $B$. cereus enterotoxin genes and proteins

\begin{tabular}{|c|c|c|c|c|}
\hline Enterotoxin & Toxin component $(\mathrm{kDa})$ & Genes & $\begin{array}{c}\text { First identification (strain/ } \\
\text { year) }\end{array}$ & References \\
\hline \multirow[t]{3}{*}{ Haemolysin BL } & B (37.5) & hblA & B-4ac & Beecher \& Macmillan (1990) \\
\hline & L1 (38.2) & $h b l D$ & (1990) & Ryan et al. (1997) \\
\hline & L2 (43.5) & $h b l C$ & & \\
\hline Non-haemolytic & A $(41.0)$ & nheA & NVH 0075/95 & Lund et al. (1996) \\
\hline \multirow[t]{2}{*}{ enterotoxin } & B (39.8) & $n h e B$ & (1996) & Heilkenbrinker et al. (2013) \\
\hline & $C(36.5)$ & nheC & & \\
\hline \multirow[t]{2}{*}{ Cytotoxin K } & CytK (34.0) & $c y t K$ & NVH 391/98 & Lund et al. (2000) \\
\hline & & & (1998) & \\
\hline \multirow[t]{2}{*}{ Enterotoxin FM } & EntFM (45.0) & entFM & FM1 & Asano et al. (1997) \\
\hline & & & (1997) & \\
\hline
\end{tabular}

Characterisation of $\mathrm{Hbl}$ by Beecher and Macmillan (1991) showed that it is a tripartite toxin, consisting of a single binding component (B) and two lytic components $\left(\mathrm{L}_{1}\right.$ and $\mathrm{L}_{2}$ ). The components, $\mathrm{B}, \mathrm{L}_{1}$, and $\mathrm{L}_{2}$ (with molecular weight in the range of $37-43 \mathrm{kDa}$ ), are encoded by $h b l A$, $h b l D$, and $h b l C$ genes, respectively, forming an operon (Ryan et al. 1997). Schoeni and Wong (1999) however showed that different $B$. cereus strains could produce multiple variants for each toxin component with varying sizes. This finding clearly demonstrated the heterogeneity of Hbl- associated genes and enteropathogenic $B$. cereus strains which might give rise to challenges in identification of $B$. cereus and its relevant virulence factors. The pore-formation upon binding, in the order of $\mathrm{B}-\mathrm{L}_{1}-\mathrm{L}_{2}$ to target cell surface is the virulence mechanism of this toxin (Jessberger et al. 2019). Maximal cytotoxicity was observed when the $\mathrm{Hbl}$ components are present in the ratio of $B: L_{1}: L_{2}=10: 1: 1$ or 10: 1: 10 (Jessberger et al. 2019). Another tripartite enterotoxin, Nhe, was identified following a diarrheal outbreak in Norway in 1995 (Lund \& Granum 1996). This toxin consists of individual components, NheA, NheB and Nhe C, encoded by nhe $A B C$ (Heilkenbrinker et al. 2013). Similar to Hbl, maximal cytotoxicity of Nhe is achieved in the presence of all components but in a certain ratio, which is Nhe $\mathrm{A}: \mathrm{B}: \mathrm{C}=$ 10:10:1 and binds sequentially in the order of Nhe $C$ - Nhe B-NheA (Lindbäck et al. 2004; Sastalla et al. 2013). Nhe B serves as a binding component whose recognition by target 
cells is aided by Nhe C (Sastalla et al. 2013). The binding of Nhe A in the third step gives rise to fully functional Nhe toxin (Heilkenbrinker et al. 2013).

Cytotoxin $\mathrm{K}$ is a single component toxin, belonging to the family of $\beta$-barrel pore-forming toxin (Yu et al. 2020) and was identified to be responsible for fatal necrotic enteritis (Lund et al. 2000). Fagerlund et al. (2004) found two CytK variants namely CytK-1 and Cytk-2 with similarity in amino acid sequence of about $89 \%$. Cytk-1 was found to be more cytotoxic to Caco-2 and Vero cells by five-fold compared to CytK-2 (Fagerlund et al. 2004). CytK-1 variant is rarely found in B. cereus and had only been identified in three $B$. cereus strains which are NVH 391/98, NVH 883/00, and INRA AF2 (Fagerlund et al. 2007). Enterotoxin FM acts as potential cell wall peptidase which plays a role in bacterial shape, motility, and biofilm formation apart from virulence (Tran et al. 2010).

\section{INTRINSIC FACTORS CONTROLLING ENTEROTOXIN PRODUCTION}

The regulation of $B$. cereus enterotoxins largely depends on the Phospholipase $\mathrm{C}$ regulator (PlcR) quorum-sensing systems in which gene expressions are regulated according to population densities (Declerck et al. 2007). Upon reaching a sufficient level due to high densities of cells, autoinducer peptide, PapR binds to the $34 \mathrm{kDa}$ PlcR protein (Declerck et al. 2007; Grenha et al. 2013). The subsequent binding of PlcR-PapR complex to palindromic sequence (recognition site) present in PlcR-controlled genes results in the gene transcription, including $B$. cereus enterotoxin genes (Gohar et al. 2008). PlcR regulon is also involved in strengthening bacterial cell wall and synthesis of antimicrobial compounds which are necessary for elimination of competing microbes in environments (Gohar et al. 2008).

Regulations of PlcR system in B. cereus are dependent on both transition state regulator, Spo0A, and nutritional state regulator, CodY (Cueppens et al. 2011; Frenzel et al. 2012). CodY enhances PlcR and PlcRcontrolled virulence genes (Frenzel et al. 2012). For instance, decreasing levels of haemolytic activity and CytK and Nhe proteins (Lindbäck et al. 2012) and reduced plcR transcript levels in $c o d Y$ mutant strain (Frenzel et al. 2012) showed that $\mathrm{CodY}$ is crucial for enteropathogenic traits of $B$. cereus. Transition state regulator Spo0A, which is required for sporulation however acts by repressing $p l c R$ transcription (Lereclus et al. 2000).

Two-component signal transduction system, ResDE mediates $B$. cereus growth and expression of enterotoxin genes under anaerobic or highly reducing conditions
(Duport et al. 2006). The study by Duport et al. (2006) presented three key findings which were $h b l$ and nhe mRNA transcript levels in res $D E$ mutants were much higher than that of $p l c R$ (encoding enterotoxin gene regulator), $\mathrm{Hbl}$ and Nhe formations in res $D E$ mutant were significantly reduced in spite of higher $h b l$ and $n h e$ transcripts, and there was no significant growth retardation between mutant and wild-type strain under fermentative growth. The first two findings indicated that ResDE regulates enterotoxin formation independent of PlcR and such a regulation possibly occurs at either translational or post-translational level. Incongruence between $p l c R$ and enterotoxin gene transcripts were also observed in the study by Jeßberger et al. (2015) which further corroborates that PlcR only partially regulates enterotoxin gene expression in $B$. cereus.

The third finding reinforced that fermentative growth in the absence of ResDE is complemented by another redox regulator such as Fumarate-nitrate reduction (Fnr) regulator. Zigha et al. (2007) showed that fnr-lacking mutant were completely unable to grow under anaerobiosis, thus showing Fnr as a more significant redox regulator than ResDE. However, Esbelin et al. (2009) found that phosphorylation of ResD (ResD P) by histidine kinase, ResE in oxygen-limiting conditions is essential to activate Fnr which subsequently binds to promoter regions of enterotoxin genes. Even though ResDE is not of utmost significance in fermentative growth, it still plays crucial role in indirect activation of enterotoxin genes via Fnr.

Flagellar proteins regulating motility were also found to contribute to enteropathogenic potential of $B$. cereus. For instance, a two-fold increase in $\mathrm{hbl}$ expression was observed in swarming (hyperflagellated) B. cereus cells (Salvetti et al. 2011). Apart from exerting control at transcriptional level, flagellar proteins are also involved in toxin secretion. Ghelardi et al. (2007) reported two strains lacking flagella were devoid of $\mathrm{Hbl}$ activity on blood agar though the strains were determined to accumulate the toxins internally via immunoblotting. The study also demonstrated that the function of flagella in toxin secretion occur independent of its role in locomotion as even flagellated but immotile strains exhibited virulence phenotype, indicating successful toxin secretion.

Nevertheless, the regulatory effects of flagellar proteins vary according to each $B$. cereus enterotoxin. A particular protein, FlhF positively regulated $\mathrm{Hbl}$ $\mathrm{L}_{2}$ formation whereas the contrary was observed for production of NheB (Mazzantini et al. 2016). This finding was partially in agreement with that of Fagerlund et al. (2010) who reported that Nhe secretion requires 
general secretory $(\mathrm{Sec})$ pathway, thus showing that Nhe secretion does not require flagellar proteins. Discrepancy was observed when Fagerlund et al. (2010) additionally reported that $\mathrm{Hbl}$ secretion also occurred independent of flagella, via Sec pathway which is contradictory to the results of Ghelardi et al. (2007) and Mazzantini et al. (2016). As a highly versatile organism, it should be of no surprise that the utilisation of different protein secretion pathways by $B$. cereus is possible according to the strains as well as environmental or test conditions.

\section{EXTRINSIC FACTORS CONTROLLING ENTEROTOXINS PRODUCTION}

Enterotoxin production in $B$. cereus is also dependent of various extrinsic factors. Nutrient composition such as contents of carbohydrates had been shown to regulate enterotoxin genes' expression. Moderately low concentrations of glucose induce production of enterotoxins whereas at high concentrations, inhibition of toxin synthesis can be observed (Duport et al. 2004; Rowan \& Anderson 1997). The high glucose content results in increased expression of catabolite control protein (CcpA) which subsequently binds to catabolite responsive elements, cre sequences identified in enterotoxin genes. This, in turn, leads to repression in enterotoxin gene expressions (van der Voort et al. 2008).

In $B$. cereus toxicoinfections, enterotoxins are produced in host intestine in which glucose availability is scarce (Jeßberger et al. 2015). Hence, it is apparent that the described repressing effect of glucose probably mediates $B$. cereus to adapt to and synthesise enterotoxins in glucose-deficient environments. Unlike $\mathrm{Hbl}$ and Nheassociated genes, absence of cre sequences in CytKencoding genes indicates that glucose-induced CcpA/ CRE repression is unlikely in CytK formation (van der Voort et al. 2008).

The fermentation of other sugars by $B$. cereus such as fructose, sucrose, and fructose-glucose mixture led to higher amounts of $\mathrm{Hbl}$ and Nhe enterotoxins than that of glucose (Ouhib-Jacobs et al. 2009). The productions of $\mathrm{Hbl}$ and Nhe were maximal upon fermentation of sucrose and glucose-fructose, respectively, though fructose as carbon source resulted in higher transcription of the enterotoxin genes mentioned (Ouhib-Jacobs et al. 2009). The disparity between the level of gene transcripts and toxin produced indicates the involvement of posttranslational regulations in the expression of enterotoxin genes, similar to that of cereulide production as reported by Kranzler et al. (2016).
Incubation temperatures are an important factor which controls the level of enterotoxin production (Cueppens et al. 2011). Park et al. (2008) reported the detection of diarrheal toxin production in all samples of cereal grains at $30{ }^{\circ} \mathrm{C}$ and none at lower temperatures (20 and $25^{\circ} \mathrm{C}$ ) even though the bacterial count were in the range of 8 to $10 \log \mathrm{CFU} / \mathrm{g}$. This indicates the regulation of enterotoxin production is more significantly dependent on the incubation temperature than the bacterial biomass. Generally, the optimum temperature for enterotoxin production is approximately $30^{\circ} \mathrm{C}$ though psychrotrophic strains produce toxins at lower temperatures (Cueppens et al. 2011).

Interestingly, certain strains have been reported to be able to synthesise similar levels of toxin at both high $\left(32{ }^{\circ} \mathrm{C}\right)$ and low $\left(10^{\circ} \mathrm{C}\right)$ temperatures in BHI (Fermanian et al. 1997). This probably occurs as the nutrients in the media exert significant control on toxin gene expression, independent of temperature. Similar temperatureindependent regulations by nutrients were also reported for emetic toxin (described in Extrinsic factors controlling emetic toxin production), These results give insights into a more prominent regulatory role of nutrients on $B$. cereus virulence.

Enterotoxin productions are also influenced by $\mathrm{pH}$ of culture medium or environment colonised by $B$. cereus. Various optimal $\mathrm{pH}$ for enterotoxin production was reported. For instance, $\mathrm{pH} 8.0$ to 9.0 for Nutrient broth (Sutherland \& Limond 1993), pH 5.8 for Brain Heart Infusion (BHI) (van Netten et al. 1990) and $\mathrm{pH} 7.0$ for BHI medium with $1.0 \% \mathrm{w} / \mathrm{v}$ glucose (Garcia-Arribas \& Kramer 1990). These findings showed that the effects of $\mathrm{pH}$ on enterotoxin formation in B. cereus differ according to nutrient compositions. Despite the variations, acidic or alkaline test conditions irrespective of culture media $(\mathrm{pH}$ below 5.0 or above 9.0) usually causes suppression of enterotoxin production (Beattie \& Williams 2002; Park et al. 2008). It is likely that extreme $\mathrm{pH}$ may have indirect control on toxin production by inhibiting bacterial growth.

\section{CONCLUSION}

As a versatile bacterium, B. cereus toxicity ranges from highly pathogenic to non-pathogenic strains that are used as probiotics. Detection of toxin synthesis is therefore imperative to differentiate the pathogenic from nonpathogenic strains, and such detection attempts could be hampered by the lack of understanding regarding the toxin biosynthesis mechanisms which are very complex and often intertwined between various regulatory and 
metabolic pathways. The genes and proteins described hitherto may not be entirely responsible for the regulation of $B$. cereus virulence factor biosynthesis as several novel genes with unknown functions have been and are being described. Continued research and extensive studies are necessary for a much better understanding of $B$. cereus virulence mechanisms which would pave the way for appropriate strategies for food preparation and handling and subsequently ensure food safety.

\section{ACKNOWLEDGEMENTS}

The authors would also like to thank RU Grant (1001/ PTEKIND/8011082) and USM Graduate Assistant Scheme for the financial assistance provided.

\section{REFERENCES}

Agata, N., Ohta, M. \& Yokoyama, K. 2002. Production of Bacillus cereus emetic toxin (cereulide) in various foods. International Journal of Food Microbiology 73(1): 23-27.

Agata, N., Ohta, M., Mori, M. \& Shibayama, K. 1999. Growth conditions of and emetic toxin production by Bacillus cereus in a defined medium with amino acids. Microbiology Immunology 43(1): 15-18.

Agata, N., Ohta, M., Arakawa, Y. \& Mori, M. 1995. The bceT gene of Bacillus cereus encodes an enterotoxic protein. Microbiology 141(4): 983-988.

Agata, N., Mori, M., Ohta, M., Suwan, S., Ohtani, I. \& Isobe, M. 1994. A novel dodecadepsipeptide, cereulide, isolated from Bacillus cereus causes vacuole formation in HEp-2 cells. FEMS Microbiology Letters 121(1): 31-34.

Apetroaie-Constantin, C., Shaheen, R., Andrup, L., Smidt, L., Rita, H. \& Salkinoja-Salonen, M. 2008. Environment driven cereulide production by emetic strains of Bacillus cereus. International Journal of Food Microbiology 127(1-2): 60-67.

Arnesen, L.P.S., Fagerlund, A. \& Granum, P.E. 2008. From soil to gut: Bacillus cereus and its food poisoning toxins. FEMS Microbiological Review Article 32(4): 579-606.

Asano, S.I., Nukumizu, Y., Bando, H., Iizuka, T. \& Yamamoto, T. 1997. Cloning of novel enterotoxin genes from Bacillus cereus and Bacillus thuringiensis. Applied and Environmental Microbiology 63(3): 1054-1057.

Beattie, S.H. \& Williams, A.G. 2002. Growth and diarrheagenic enterotoxin formation by strains of Bacillus cereus in vitro in controlled fermentations and in situ in food products and a model food system. Food Microbiology 93: 329-340.

Beecher, D.J. \& Macmillan, J.D. 1991. Characterization of the components of haemolysin BL from Bacillus cereus. Infection and Immunity 59(5): 1778-1784.

Beecher, D.J. \& Macmillan, J.D. 1990. A novel biocompetent haemolysin from Bacillus cereus. Infection and Immunity 58(7): 2220-2227.
Bottone, E.J. 2010. Bacillus cereus, a volatile human pathogen. Clinical Microbiology Reviews 23(2): 382-392.

Burgess, G. \& Horwwod, P. 2006. A Report for the Rural Industries and Development Corporation. Development of Improved Molecular Detection Methods for B. cereus Toxins. The Genes Responsible for the Emetic Toxin were Discovered and New Tests Developed. Australia: Rural Industries and Development Corporation.

Carlin, F., Fricker, M., Pielaat, A., Heisterkamp, S., Shaheen, R., Salonen, M.S., Svensson, B., Nguyen-thé, C. \& EhlingSchulz, M. 2006. Emetic toxin-producing strains of Bacillus cereus show distinct characteristics within the Bacillus cereus group. International Journal of Food Microbiology 109(1-2): 132-138.

Carroll, L.M., Wiedmann, M., Mukherjee, M., Nicholas, D.C., Mingle, L.A., Dumas, N.B., Cole, J.A. \& Kovac, J. 2019. Characterization of emetic and diarrheal Bacillus cereus strains from a 2016 foodborne outbreak using wholegenome sequencing: Addressing the microbiological, epidemiological, and bioinformatic challenges. Frontiers in Microbiology 10(144): 1-20.

Carter, L., Chase, H.R., Gieseker, C.M., Hasbrouck, N.R., Stine, C.B., Khan, A., Ewing-Peeples, L.J., Tall, B.D. \& Gopinath, G.R. 2018. Analysis of enterotoxigenic Bacillus cereus strains from dried foods using whole genome sequencing, multi-locus sequence analysis and toxin gene prevalence and distribution using endpoint PCR analysis. International Journal of Food Microbiology 284: 31-39.

Choma, C. \& Granum, P.E. 2002. The enterotoxin T (BcET) from Bacillus cereus can probably not contribute to food poisoning. FEMS Microbiology Letters 217(1): 115-119.

Cueppens, S., Rajkovic, A., Heyndrickx, M., Tsillia, V., Wiele, T.V.D., Boon, N. \& Uyttendaele, M. 2011. Regulation of toxin production by Bacillus cereus and its food safety implications. Critical Reviews in Microbiology 37(3): 188-213.

Declerck, N., Bouillaut, L., Chaix, D., Rughani, N., Slamti, L., Hoh, F., Lereclus, D. \& Arold, S.T. 2007. Structure of PlcR: Insights into virulence regulation and evolution of quorum sensing in Gram-positive bacteria PNAS 104(47): 18490-18495.

Dierick, K., Van Coillie, E., Swiecicka, I., Meyfroidt, G., Devlieger, H., Meulemans, A., Hoedemaekers, G., Fourie, L., Heyndrickx, M. \& Mahillon, J. 2005. Fatal family outbreak of Bacillus cereus associated food poisoning. Journal of Clinical Microbiology 43(8): 4277-4279.

Duport, C., Zigha, A., Rosenfeld, E. \& Schmitt, P. 2006. Control of enterotoxin gene expression in Bacillus cereus F4430/73 involves the redox-sensitive ResDE signal transduction system. Journal of Bacteriology 188(18): 6640-6651.

Duport, C., Thomassin, S., Bourel, G. \& Philippe, S. 2004. Anaerobiosis and low specific growth rates enhance haemolysin BL production by Bacillus cereus F4430/73. Archives of Microbiology 182(1): 90-95. 
Ehling-Schulz, M., Fricker, M. \& Gohar, M. 2015. Food-bacteria interplay: Pathometabolism of emetic Bacillus cereus. Frontiers in Microbiology 6: 704.

Ehling-Schulz, M., Fricker, M., Grallert, H., Rieck, P., Wagner, M. \& Scherer, S. 2006. Cereulide synthetase gene cluster from emetic Bacillus cereus: Structure and location on a mega virulence plasmid related to Bacillus anthracis toxin plasmid pXO1. BMC Microbiology 6: 20.

Ehling-Schulz, M., Vukov, N., Schulz, A., Shaheen, R., Andersson, M., Märtlbauer, E. \& Scherer, S. 2005. Identification and partial characterization of the nonribosomal peptide synthetase gene responsible for cereulide production in emetic Bacillus cereus. Applied and Environmental Microbiology 71(1): 105-113.

Esbelin, J., Armengaud, J., Zigha, A. \& Duport, C. 2009. ResDEdependent regulation of enterotoxin gene expression in Bacillus cereus: Evidence for multiple modes of binding for ResD and interaction with Fnr. Journal of Bacteriology 191(13): 4419-4426.

Fagerlund, A., Lindbäck, T. \& Granum, P.E. 2010. Bacillus cereus cytotoxins $\mathrm{Hbl}$, Nhe and CytK are secreted via the Sec translocation pathway. BMC Microbiology 10: 304.

Fagerlund, A., Brillard, J., Fürst, R., Guinebretière, M.H. \& Granum, P.E. 2007. Toxin production in a rare and genetically remote cluster of strains of the Bacillus cereus group. BMC Microbiology 7: 43.

Fagerlund, A., Ween, O., Lund, T., Hardy, S.P. \& Granum, P.E. 2004. Genetic and functional analysis of the cytK family of genes in Bacillus cereus. Microbiology 150(Pt 8): 26892697.

Fermanian, C., Lapeyre, C., Frémy, J.M. \& Claisse, M. 1997. Diarrheal toxin production at low temperature by selected strains of Bacillus cereus. Journal of Dairy Research 64(4): 551-559.

Finlay, W.J.J., Logan, N.A. \& Sutherland, A.D. 2002. Bacillus cereus emetic toxin production in relation to dissolved oxygen tension and sporulation. Food Microbiology 19(5): 423-430.

Finlay, W.J.J., Logan, N.A. \& Sutherland, A.D. 2000. Bacillus cereus produces most emetic toxin at lower temperatures. Letters in Applied Microbiology 31(5): 385-389.

Frenzel, E., Doll, V., Pauthner, M., Lücking, G., Scherer, S. \& Ehling-Schulz, M. 2012. CodY orchestrates the expression of virulence determinants in emetic Bacillus cereus by impacting key regulatory circuits. Molecular Microbiology 85(1): 67-88.

Garcia-Aribas, M.L. \& Kramer, J.M. 1990. The effect of glucose, starch, and $\mathrm{pH}$ on growth, enterotoxin and haemolysin production by strains of Bacillus cereus associated with food poisoning and non-gastrointesinal infection. International Journal of Food Microbiology 11(1): 21-33.

Ghelardi, E., Celandroni, F., Salvetti, S., Ceragioli, M., Beecher, D.J., Senesi, S. \& Wong, A.C.L. 2007. Swarming behavior of and hemolysin BL secretion in Bacillus cereus. Applied and Environmental Microbiology 73(12): 4089-4093.
Gohar, M., Faegri, K., Perchat, S., Ravnum, S., Økstad, O.A. Gominet, M., Kolstø, A.B. \& Lereclus, D. 2008. The PlcR virulence regulon of Bacillus cereus. PLos ONE 3(7): e2793.

Grenha, R., Slamti, L., Nicaise, M., Refes, Y., Lereclus, D. \& Nessler, S. 2013. Structural basis for the activation mechanism of the PlcR virulence regulator by the quorum sensing signal peptide PapR. PNAS 110(3): 1047-1052.

Guinebretière, M.H., Auger, S., Galleron, N., Contzen, M., De Sarrau, B., De Buyser, M.L., Lamberet, G., Fagerlund, A., Granum, P.E., Lereclus, D., DeVos, P., Nguyen-thé, C. \& Sorokin, A. 2013. Bacillus cytotoxicus sp. nov. is a novel thermotolerant species of the Bacillus cereus group occasionally associated with food poisoning. International Journal of Systematic and Evolutionary Microbiology 63(Pt 1): 31-40.

Häggblom, M.M., Apetroaie, C., Andersson, M.A. \& SalkinojaSalonen, M.S. 2002. Quantitative analysis of cereulide, the emetic toxin of Bacillus cereus, produced under various conditions. Applied and Environmental Microbiology 68(5): 2479-2483

Hansen, B.M., Høiby, P.E., Jensen, G.B. \& Hendriksen, N.B. 2003. The Bacillus cereus bceT enterotoxin sequence reappraised. FEMS Microbiology Letters 223(1): 21-24.

Heilkenbrinker, U., Dietrich, R., Didier, R., Zhu, K., Lindbäck, T., Granum, P.E. \& Märtlbauer, E. 2013. Complex formation between NheB and NheC is necessary to induce cytotoxic activity by the three-component Bacillus cereus Nhe enterotoxin. PLoS ONE 8(4): e63104.

Ichikawa, K., Gakumazawa, M., Inaba, A., Shiga, K., Takeshita, S., Mori, M. \& Kikuchi, N. 2010. Acute encephalopathy of Bacillus cereus mimicking Reye syndrome. Brain and Development 32(8): 688-690.

Jääskeläinen, E.L., Häggblom, M.M., Andersson, M.A. \& Salkinoja-Salonen, M.S. 2004. Atmospheric oxygen and other conditions affecting the production of cereulide by Bacillus cereus in food. International Journal of Food Microbiology 96(1): 75-83.

Jääskeläinen, E.L., Häggblom, M.M., Andersson, M.A., Vanne, L. \& Salkinoja-Salonen, M.S. 2003. Potential of Bacillus cereus for producing an emetic toxin, cereulide, in bakery products: Quantitative analysis by chemical and biological methods. Journal of Food Protection 66(6): 1047-1054.

Jeßberger, N., Kry, V.M., Rademacher, C., Böhm, M.E., Mohr, A.K., Ehling-Schulz, M., Scherer, S. \& Märtlbauer, E. 2015. From genome to toxicity: A combinatory approach highlights the complexity of enterotoxin production in Bacillus cereus. Frontiers in Microbiology 6: 560.

Jessberger, N., Dietrich, R., Schwemmer, S., Tausch, F., Schwenk, V., Didier, A. \& Märtlbauer, E. 2019. Binding to the target cell surface is the crucial step in pore formation of haemolysin BL from Bacillus cereus. MPDI Toxins 11(5): 281 .

Kranzler, M., Stollewerk, K., Rouzeau-Szynalski, K., Blayo, L., Sulyok, M. \& Ehling-Schulz, M. 2016. Temperature exerts 
control of Bacillus cereus emetic toxin production on posttranscriptional levels. Frontiers in Microbiology 7: 1640

Lereclus, D., Agaisse, H., Grandvalet, C., Salamitou, S. \& Gominet, M. 2000. Regulation of toxin and virulence gene transcription in Bacillus thuringiensis. International Journal of Medical Microbiology 290(4-5): 295-299.

Lindbäck, T., Fagerlund, A., Rødland, M.S. \& Granum, P.E. 2004. Characterization of Bacillus cereus Nhe enterotoxin. Microbiology 150(Pt 2): 3959-3967.

Lindbäck, T., Mols, M., Basset, C., Granum, P.E., Kuipers, O.P. \& Kovacs, A.T. 2012. CodY, a pleiotropic regulator, influences multicellular behaviour and efficient production of virulence factors in Bacillus cereus. Environmental Microbiology 14(8): 2233-2246.

Lücking, G., Dommel, M.K., Scherer, S., Fouet, A. \& EhlingSchulz, M. 2009. Cereulide synthesis in emetic Bacillus cereus is controlled by the transition state regulator $\mathrm{AbrB}$, but not by the virulence regulator PlcR. Microbiology $155(\mathrm{Pt}$ 3): 922-931.

Lücking, G., Frenzel, E., Rütschle, A., Marxen, S., Stark, T.D., Hofmann, T., Scherer, S. \& Ehling-Schulz, M. 2015. Ces locus embedded proteins control the non-ribosomal synthesis of the cereulide toxin in emetic Bacillus cereus on multiple levels. Frontiers in Microbiology 6: 1101.

Lund, T., De Buyser, M.L. \& Granum, P.E. 2000. A new cytotoxin from Bacillus cereus that may cause necrotic enteritis. Molecular Microbiology 38(2): 254-261.

Lund, T. \& Granum, P.E. 1996. Characterisation of a nonhaemolytic enterotoxin complex from Bacillus cereus isolated after a foodborne outbreak. FEMS Microbiology Letters 141(2-3): 151-156.

Mahler, H., Pasi, A., Kramer, J.M., Schulte, P., Scoging, A.C., Bär, W. \& Krähenbühl, S. 1997 Fulminant liver failure in association with the emetic toxin of Bacillus cereus. The New England Journal of Medicine 336(16): 1142-1148.

Majed, R., Faille, C., Kallassy, M. \& Gohar, M. 2016. Bacillus cereus biofilms-same, only different. Frontiers in Microbiology 7: 1054.

Marxen, S., Stark, T.D., Frenzel, E., Rütschle, A., Lücking, G., Pürstinger, G., Pohl, E.E., Ehling-Schulz, M., Scherer, S. \& Hofmann, T. 2015. Chemodiversity of cereulide, the emetic toxin of Bacillus cereus. Analytical and Bioanalytical Chemistry 407(9): 2439-2453.

Mazzantini, D., Celandroni, F., Salvetti, S., Gueye, S.A., Lupetti, A., Senesi, S. \& Ghelardi, E. 2016. FlhF is required for swarming motility and full pathogenicity of Bacillus cereus. Frontiers in Microbiology 19: 1644.

Messelhäusser, U., Frenzel, E., Blöchinger, C., Zucker, R., Kämpf, P. \& Ehling-Schulz, M. 2014. Emetic Bacillus cereus are more volatile than thought: Recent foodborne outbreaks and prevalence study in Bavaria (2005-2013). Biomedical Research International 2014: 465603.

Naranjo, M., Denayer, S., Botteldoorn, N., Delbrassinne, L., Veys, J., Waegenaere, J., Sirtaine, N., Driesen, R.B., Sipido, K.R., Mahillon, J. \& Dierick, K. 2011. Sudden death of a young adult associated with Bacillus cereus food poisoning. Journal of Clinical Microbiology 49(12): 4379-4381.

Oh, M.H. \& Cox, J.M. 2010. Development and application of a centrifugation-plating method to study the biodiversity of Bacillus species in rice products. Food Control 21(1): 7-12.

Ouhib-Jacobs, O., Lindley, N.D., Schmitt, P. \& Clavel, T. 2009. Fructose and glucose mediate enterotoxin production and anaerobic metabolism of Bacillus cereus ATCC 14579. Journal of Applied Microbiology 107(3): 821-829.

Paananen, A., Mikkola, R., Sareneva, T., Matikainen, S., Hess, M., Andersson, M., Julkunen, I., Salkonoja-Salonen, M.S. \& Timonen, T. 2002. Inhibition of human natural killer cell activity by cereulide, an emetic toxin from Bacillus cereus. Clinical and Experimental Immunology 129(3): 420-428.

Park, Y.B., Kim, J.B., Jin, Y.G. \& Oh, D.H. 2008. Effect of temperatures on the enterotoxin production of Bacillus cereus in cereal grains. Food Science and Biotechnology 17: 824-828.

Phat, C., Kim, S., Park, J. \& Lee, C. 2016. Detection of emetic toxin genes and in Bacillus cereus isolated from food and their production of cereulide in liquid culture. Journal of Food Safety 37(1): e12293.

Rajkovic, A., Uyttendaele, M., Sylvie-Anne, O., Jääskeläinen, E., Salkinoja-Salonen, M. \& Debevere, J. 2006. Influence of type of food on the kinetics and overall production of Bacillus cereus emetic toxin. Journal of Food Protection 69(4): 847-852.

Rasko, D.A., Rosovitz, M.J., Økstad, O.A., Fouts, D.E., Jiang, L., Cer, R.Z., Kolstø, A.B., Gill, S.R. \& Ravel, J. 2007. Complete sequence analysis of novel plasmids from emetic and periodontal Bacillus cereus isolates reveals a common evolutionary history among the $B$. cereus group plasmids, including Bacillus anthracis pXO1. Journal of Bacteriology 189(1): 52-64.

Rouzeau-Szynalski, K., Stollewerk, K., Messelhäusser, U. \& Ehling-Schulz, E. 2020. Why be serious about emetic Bacillus cereus: Cereulide production and industrial challenges. Food Microbiology 85: 103279.

Rowan, N.J. \& Anderson, J.G. 1997. Maltodextrin stimulates growth of Bacillus cereus and synthesis of diarrheal enterotoxin in infant milk formulae. Applied Environmental Microbiology 63(3): 1182-1184.

Ryan, P.A., McMillan, J.D. \& Zilinskas, B.A. 1997. Molecular cloning and characterization of the genes encoding the $\mathrm{L}_{1}$ and $\mathrm{L}_{2}$ components of haemolysin $\mathrm{BL}$ from Bacillus cereus. Journal of Bacteriology 179(8): 2551-2556.

Saleh, M., Al Nakib, M., Doloy, A., Jacqmin, S., Ghiglione, S., Verroust, N., Poyart, C. \& Ozier, Y. 2012. Bacillus cereus, an unusual cause of fulminant liver failure: Diagnosis may prevent liver transplantation. Journal of Medical Microbiology 61(Pt 5): 743-745.

Salvetti, S., Faegri, K., Ghelardi, E., Kolstø, A.B. \& Senesi, S. 2011. Global gene expression profile for swarming Bacillus cereus bacteria. Applied and Environmental Microbiology 77(15): 5149-5156. 
Sastalla, I., Fattah, R., Coppage, N., Nandy, P., Crown, D. Pomerantsev, A.P. \& Leppla, S.H. 2013. The Bacillus cereus $\mathrm{Hbl}$ and Nhe tripartite enterotoxin components available assemble sequentially on the surface of target cells and are not interchangeable. PLOS ONE 8(10): e76955.

Schoeni, J.L. \& Wong, A.C.L. 1999. Heterogeneity observed in the components of hemolysin BL, an enterotoxin produced by Bacillus cereus. International Journal of Food Microbiology 53(2-3): 159-167.

Setlow, P. 2014. Germination of spores of Bacillus species: What we know and do not know. Journal of Bacteriology 196(7): 1297-1305.

Shaheen, R., Andersson, M.A., Apetroaie-Constantin, C., Schulz, A., Ehling-Schulz, M., Ollilainen, M. \& SalkinojaSalonen, M. 2006. Potential of selected infant food formulas for production of Bacillus cereus emetic toxin, cereulide. International Journal of Food Microbiology 107(3): 287294.

Soni, A., Oey, I., Silcock, P. \& Bremer, P. 2016. Bacillus spores in the food industry: A review on resistance and response to novel inactivation technologies. Comprehensive Reviews in Food Science and Food Technology 15(6): 1139-1148.

Sutherland, A.D. \& Limond, A.M. 1993. Influence of $\mathrm{pH}$ and sugars on the growth and production of diarrheagenic toxin by Bacillus cereus. Journal of Dairy Research 60(23): $575-580$

Svensson, B., Monthán, A., Guinebretière, M.H., Nguyen-thé, C. \& Christiansson, A. 2007. Toxin production potential and the detection of toxin genes among strains of the Bacillus cereus group isolated along the dairy production chain. International Dairy Journal 17(10): 1201-1208.

Tewari, A., Singh, S.P. \& Singh, R. 2015. Incidence and enterotoxigenic profile of Bacillus cereus in meat and meat products of Uttarakhand, India. Journal of Food Science Technology 52(3): 1796-1801.

Tian, S., Xiong, H., Geng, P., Yuan, Z. \& Hu, X. 2019. CesH represses cereulide synthesis as an alpha/beta fold hydrolase in Bacillus cereus. MDPI Toxins 11(4): 231.

Toh, M., Moffitt, M.C., Henrichsen, L., Raftery, M., Barrow, K., Cox, J.M., Marquis, C.P. \& Neilan, B.A. 2004. Cereulide, the emetic toxin of Bacillus cereus, is putatively a product of nonribosomal peptide synthesis. Journal of Applied Microbiology 97(5): 992-1000.
Tran, S.L., Guillemet, E., Gohar, M., Lereclus, D. \& Ramarao, N. 2010. CwpFM (EntFM) is a Bacillus cereus potential cell wall peptidase implicated in adhesion, biofilm formation, and virulence. Journal of Bacteriology 192(10): 2638-2642.

van der Voort, M., Kuipers, O.P., Buist, G., de Vos, W.M. \& Abee, T. 2008. Assessment of CcpA-mediated catabolite control of gene expression in Bacillus cereus ATCC 14579. BMC Microbiology 8: 62.

van Netten, P.A., van De Moosdijk, P., van Hoensel, D.A. \& Perales, I. 1990. Psychrotrophic strains of Bacillus cereus producing enterotoxin. Journal of Applied Bacteriology 69(1): 73-79.

Vangoitsenhoven, R., Rondas, D., Crèvecoeur, I., D'Hertog, W., Baatsen, P., Masini, M., Andjelkovic, M., Van Loco, J., Matthys, C., Mathieu, C., Overbergh, L. \& Van der Schueren, B. 2014. Foodborne cereulide causes beta-cell dysfunction and apoptosis. PLoS ONE 9(8): e104866.

Yu, S., Yu, P., Wang, J., Li, C., Guo, H., Liu, C., Kong, L., Yu, L., Wu, S., Lei, T., Chen, M., Zeng, H., Pang, R., Zhang, Y., Wei, X., Zhang, J., Wu, Q. \& Ding, Y. 2020. A study on prevalence and characterization of Bacillus cereus in ready-to-eat foods in China. Frontiers in Microbiology 10: 3043.

Zigha, A., Rosenfeld, E., Schmitt, P. \& Duport, C. 2007. The redox regulator $\mathrm{Fnr}$ is required for fermentative growth and enterotoxin synthesis in Bacillus cereus F4430/73. Journal of Bacteriology 189(7): 2813-2824.

Yugenraj Navaneethan \& Mohd Esah Effarizah*

Food Technology Division

School of Industrial Technology

Universiti Sains Malaysia

11800 Minden, Penang

Malaysia

Norli Ismail

Environmental Technology Division

School of Industrial Technology

Universiti Sains Malaysia

11800 Minden, Penang

Malaysia

*Corresponding author; email: effarizah@usm.my

Received: 20 May 2020

Accepted: 9 October 2020 